\title{
First record of Sparganium subglobosum Morong (Typhaceae) from Korea
}

\author{
Chang-Kun Lim\#, Juhyeon Kim, Young Chul Kim, Chae Eun Lim² and Hyosig Won* \\ Department of Biological Science and Institute of Basic Sciences, Daegu University, Gyeongsan 38453, Korea \\ ${ }^{1}$ Department of Biology, Gangneung-Wonju National University, Gangneung 25457, Korea \\ ${ }^{2}$ National Institute of Biological Resources, Incheon 22689, Korea \\ ${ }^{\#}$ Current Address: Green Plant Research Institute, Yongin 16954, Korea \\ (Received 9 December 2017; Revised 21 December 2017; Accepted 21 December 2017) \\ 한반도 미기록식물 가는흑삼릉 \\ 임창건 ${ }^{*}$ 김주현 · 김영철 ${ }^{1}$. 임채은 ${ }^{2}$ 원효식* \\ 대구대학교 생명과학과, ${ }^{1 ㄱ ㅏ ㅇ ㄹ ㅡ ㅇ ㅇ ㅝ ㄴ ㅈ ㅜ ㄷ ㅐ ㅎ ㅏ ㄱ ㄱ ㅛ ~ ㅅ ㅐ ㅇ ㅁ ㅜ ㄹ ㅎ ㅏ ㄱ ㄱ ㅘ, ~}{ }^{2}$ 국립생물자원관, "녹색식물연구소 (현주소)
}

\begin{abstract}
We report the distribution of Sparganium subglobosum Morong (Typhaceae) for the first time in Korea. Sparganium subglobosum is readily distinguishable from other Korea Sparganium species by having a short plant height, narrow leaves $(\leq 4 \mathrm{~mm})$, thin inflorescence branches, and a ripe fruiting head globose and ca. $1 \mathrm{~cm}$ in diam. The species is under great threat of local extinction due to a recent disturbance of one of only two known distribution sites. Further conservation plans for S. subglobosum and surveys are needed. We provide a revised key to five Sparganium species of Korea, with descriptions, pictures, and figures of S. subglobosum.
\end{abstract}

Keywords: unrecorded species, Sparganium subglobosum, Typhaceae, endangered, conservation

적 요: 부들과에 속하는 한반도 미기록식물인 가는흑삼릉(Sparganium subglobosum Morong)을 최초로 보고 한다. 가는흑삼릉은 작은 키, 폭 $4 \mathrm{~mm}$ 이하로 좁은 잎, $1-2$ 회 분지하는 가는 화축, 성숙시 지름 약 $1 \mathrm{~cm}$ 인 구형 두상 화수 등의 특징에 있어 기존에 우리나라에서 보고된 다른 흑삼릉속 식물과 구분된다. 현재까지 확 인된 가는흑삼릉의 2 개 분포지 중 1 곳은 최근 심하게 교란되어 지역적인 멸종위협에 놓여 있는 상태이다. 가는흑삼릉에 대한 보전 대책 마련 및 추가적인 분포지 확인이 필요하다. 가는흑삼릉의 기재문, 사진 및 도 해 외에 우리나라 흑삼릉속 식물의 검색표를 제시한다.

주요어: 미기록종, 가는흑삼릉, 부들과, 멸종위기, 보전

Sparganium is a genus of \pm 14 aquatic species, distributed in temperate and cool regions of Eurasia and North America, also in Oceania (Cook and Nicholls, 1986, 1987). Sparganium species are perennial herbs, emergent from shallow water or wholly submerged and floating, and comprise the most important plants in the riverside and lakeshore wetlands plant communities (Kubitzki, 1998). Also, they provide shelters and food for wildlife, and help reduce erosion of river banks (Cook and
Nicholls, 1986). Sparganium species show morphological adaptations common to many other aquatic plant groups, such as monoecy, wind-pollination, floral reduction, seeds capable of long-distance dispersal, and vegetative propagation by rhizomes and stolons (Cook, 1988; Barrett et al., 1993; Santamaria, 2002). Sparganium has traditionally been placed in the monogeneric family Sparganiaceae, but recent classification scheme placed both Typha and Sparganium in Typhaceae (The Angiosperm

\footnotetext{
*Author for correspondence: wonhs@daegu.ac.kr
} 
Phylogeny Group, 2016). Sparganium is characterized by globose head-like inflorescence, while Typha is elongate, cylindrical spike-like (Kubitzki, 1998).

For Korean flora, four Sparganium species have been recognized, such as $S$. erectum L., $S$. japonicum Rothert, $S$. fallax Graebn., and S. hyperboreum Laest. ex Beurl. (Lee, 1980; Lee, 1996; Lee, 2006; Kim and Choi, 2007; Kim et al., 2010). Im (2000) reported three Sparganium species for Korea, i.e., S. stoloniferum (Buch.-Ham. ex Graebn.) Buch.-Ham. ex Juz. ( $=S$. erectum, according to Cook and Nicholls [1987]), $S$. simplex Huds. ( $=$ S. emersum Rehmann, according to Cook and Nicholls [1986]), and S. japonicum Rothert. Cook and Nicholls $(1986,1987)$, in their revision of Sparganium species in the world, suggested the presence of $S$. erectum subsp. stoloniferum, S. eurycarpum subsp. coreanum, S. hyperboreum, S. emersum subsp. emersum, S. japonicum, and S. glomeratum in Korea, but mostly in northern part of Korea.

While working on DNA barcoding of Korean Typhaceae, including both Sparganium and Typha, we have recognized a Sparganium species new to flora of Korea, distinct from other Korean taxa both in overall morphology and sequence characteristics (data not shown). The new Sparganium species was identified as S. subglobosum Morong. Although Sun and Simpson (2010) suggested the presence of S. subglobosum in Korea, no one has ever reported or provided evidence proving the presence of $S$. subglobosum so far. Here we are presenting a description and diagram of $S$. subglobosum, and a revised key to Sparganium species in Korea.

\section{Taxonomic Treatment}

Sparganium subglobosum Morong, Bull. Torrey Bot. Club 15: 81, 1888.-TYPE: New Zealand, Bay of Islands, U.S. Exploring Expedition under Command of Capt. Wilkes (holotype: GH, not seen). Figs. 1 \& 2 .

Sparganium angustifolium var. latifolium Benth., Fl. Austral. 7: 161, 1878.

Sparganium stenophyllum Maxim. ex Meinsh., Bull. Soc. Imp. Naturalistes Moscou, n.s., 3: 171, 1890.

Sparganium antipodum Graebn., Allg. Bot. Z. Syst. 4: 33, 1898. Sparganium nipponicum Makino, Fl. Japan: 523, 1925.

Vernacular name: 가는흑삼릉 (Korean, Ka-neun-heuksam-reung), ヒメミクリ (Japanese, Himemikuri), 狭叶黑三 棱 (Chinense, Xia-ye-hei-san-leng), burr-reed, maru (New Zealand).

Herbs, perennial, monoecious, $60-100 \mathrm{~cm}$ tall, glabrous, aquatic; rhizome creeping; stems simple or branched, slender. Leaves alternate, distichous, emergent or floating, sheathed at base, linear, 40-80 cm long, 3-4 mm wide, flat adaxially, keeled abaxially, basally triangular. Inflorescence globose, unisexual heads on upper part of stems, inflorescence axis one or two; main inflorescence axis ca. $20 \mathrm{~cm}$ long, $2 \mathrm{~mm}$ in diam., with basal 3 to 4 female heads and 6-7 male heads above; lateral inflorescence axillary, ca. $7 \mathrm{~cm}$ long, with one or two basal female heads and 3 to 4 male heads above; heads usually sessile, except the one at lateral inflorescence; female heads diam. ca. $1 \mathrm{~cm}$; male heads diam. 5-6 mm, 11-13 mm when anthers mature; bracts leaf-like, spreading to descendingspreading, basal one $15-16 \mathrm{~cm}$ long. Flowers minute, unisexual, densely crowded in globose heads; male flowers: perianth segments 3 to 4 , spathulate, ca. $2 \mathrm{~mm}$ long, stamens 3 or more, filaments ca. $4 \mathrm{~mm}$ long, anthers basifixed, white, oblong, ca. $0.7 \mathrm{~mm}$ long, $0.2 \mathrm{~mm}$ wide, longitudinally dehiscent, caducous; female flowers bracteolate; perianth segments spathulate, ca. $2 \mathrm{~mm}$ long; ovary sessile, narrowly fusiform, ca. $4 \mathrm{~mm}$ long, 1-loculed; styles simple, $0.5 \mathrm{~mm}$ long, with a unilateral stigma, ca. $1.2 \mathrm{~mm}$ long; ovule 1, pendulous. Fruit nutlike, obovoid, ca. $4 \mathrm{~mm}$ long, indehiscent. Seed 1 per fruit, ovoid, ca $1.5 \mathrm{~mm}$ long.

Phenology: flowering June-August and fruiting JulySeptember.

Distribution: Korea, China, Japan, Russia (Far East), Vietnam; New Guinea, Australia, New Zealand.

Specimen examined: KOREA. Gangwon-do: Goseong-gun, Ganseong-eup, Ha-ri, Bukcheon, at Bukcheon Bridge, $38^{\circ} 23^{\prime} 4.4^{\prime \prime} \mathrm{N}, 128^{\circ} 27^{\prime} 29^{\prime \prime} \mathrm{E}$, alt. $10 \mathrm{~m}$, 4 Sep 2009, J. D. Jung \& H. R. 0909124-1 (KB), 0909124-3 (KB); Goseong-gun, Toseong-myeon, Bongpo-ri, Lake Cheonjin, south inlet of the lake, 38 $15^{\prime} 07.7^{\prime \prime} \mathrm{N}, 128^{\circ} 33^{\prime} 15.7^{\prime \prime}$, alt. 19 m, 23 Jun 2013, H. Won 9655 (DGU); Goseong-gun, Toseong-myeon, Bongpori, Lake Cheonjin, south inlet of the lake, $38^{\circ} 15^{\prime} 07.4^{\prime \prime} \mathrm{N}$, $128^{\circ} 33^{\prime} 15.0^{\prime \prime} \mathrm{E}$, alt. $19 \mathrm{~m}, 7 \mathrm{Jul}$ 2014, H. Won et al. 11234 (DGU); Goseong-gun, Toseong-myeon, Bongpo-ri, Lake Cheonjin, 18 Jun 2011, J.-S. Kim CJH1054 (KB); Goseonggun, Toseong-myeon, Bongpo-ri, Lake Cheonjin, $38^{\circ} 15^{\prime} 09.5^{\prime \prime} \mathrm{N}, 128^{\circ} 33^{\prime} 16.84^{\prime \prime} \mathrm{E}, 7$ Sep 2012, J.-S. Kim CJH1006 (KB).

JAPAN. Hokkaido: Akan-gun, Tsurui-mura, Moor-Onnenai, in intermediate moor, 17 Aug 1981, K. Takita 824 (KYO). Honshu: Chiba Pref., Ichikawa City, Junsai-numa, in 1894, $T$. Makino s.n. (KYO); Chiba Pref., Chosei-gun, Ichinomiya-cho, Ichimatsu, 11 Jul 1937, T. Makino s.n. (KYO); Hyogo Pref., en route from Monobe to Orotani, Sumoto City, $34^{\circ} 20^{\prime} \mathrm{N}$, 135 54'E, alt. 20-80 m, 29 Jul 1994, N. Kurosaki \& S. Miyake 

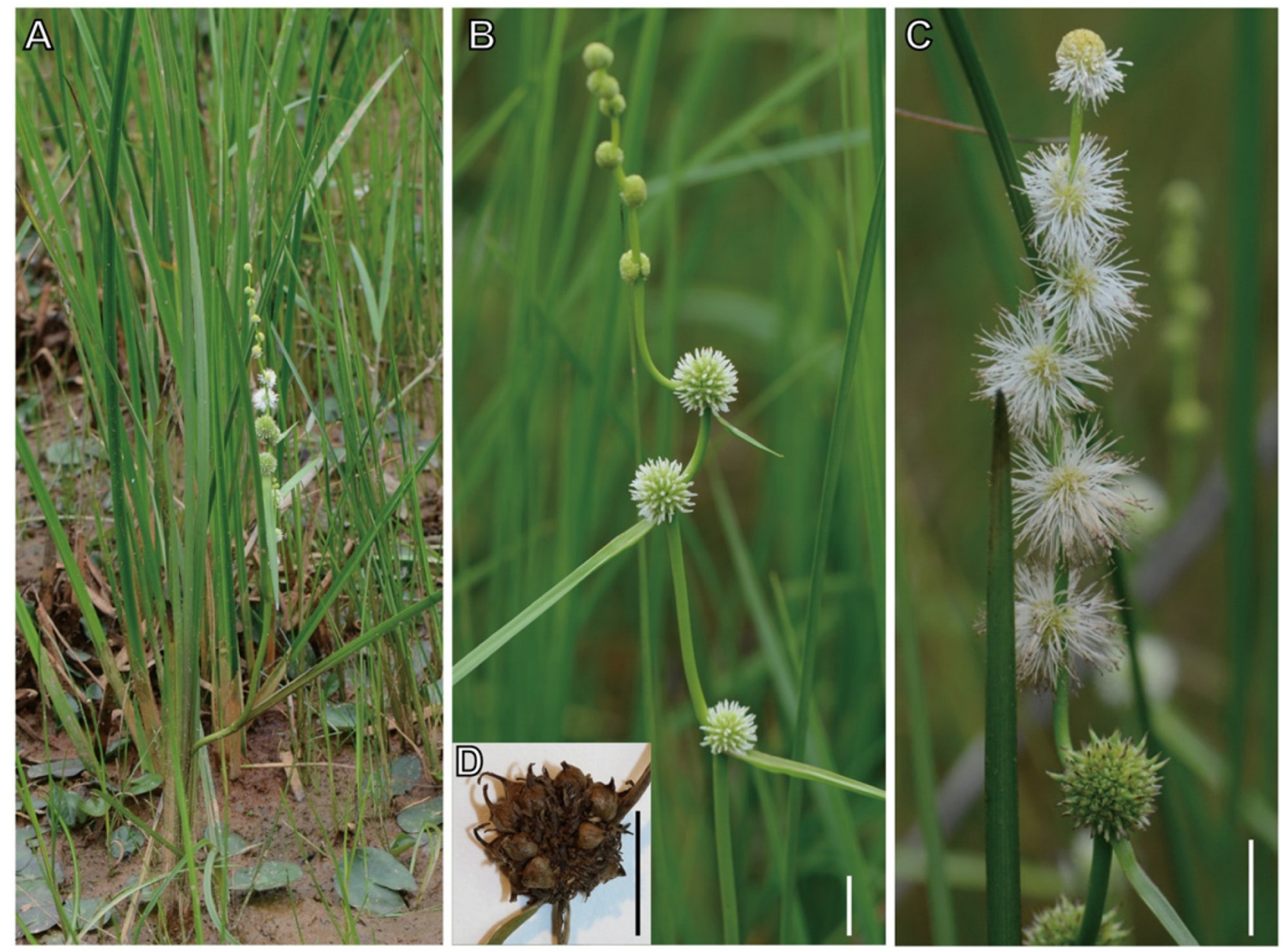

Fig. 1. Habit and morphology of S. subglobosum Morong (Typhaceae). A. Habit. B. Inflorescence with matured female head (Jun 2013 ). C. Matured male heads (Jul 2014). D. Matured nutlike fruit (Sep 2011). Scale bars $=1 \mathrm{~cm}$.

1460 (MAK); Miyagi Pref., Miyagi-gun, Rihu-machi, Akanuma, 19 Aug 1973, T. Naito s.n. (KYO); Nagano Pref., Kitaazumi-gun, Hakuba-mura, Oyemi-moor, alt. 500-600 m, 15 Aug 1979, E. Kinoshita 1011 (KYO); Nagano Pref., Shimoina Co., Tonobayashi, Omura, Anan Town, $35^{\circ} 21^{\prime} \mathrm{N}$, $137^{\circ} 45^{\prime} \mathrm{E}$, alt. 810 m, 11 Aug 1957, K. Asano 111721 (MAK); Osaka Pref., Shijonawate-shi, around Muroike Ponds, alt. ca. 300 m, 1 Aug 1992, K. Seto 38791 (TNS); Osaka Pref., Ibarakishi, Sendaiji, 14 Sep 2007, T. Sawada et al. 787 (TNS); Wakayama Pref., Higashi-muro-gun, Koza-cho, en route from Tawara to Sabe, $33^{\circ} 32^{\prime} 35-50^{\prime \prime} \mathrm{N}, 135^{\circ} 51^{\prime} 50^{\prime \prime}-52^{\prime} 10^{\prime \prime} \mathrm{E}$, alt. $0 \mathrm{~m}$, 7 Aug 2004, S. Fujii 10237 (KYO [2 sheets], MAK [2 sheets]). Kyushu: Saga Pref., Karatsu-shi, Nanayamakebaru, Kashihara

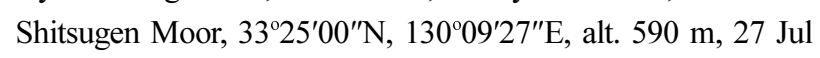
2009, C. Sato 3433 (KYO); Kumamoto Pref., Aso-shi, Ichinomiya-machi, Kiotoshi Stock Farm, $33^{\circ} 01$ N, $131^{\circ} 07^{\prime} \mathrm{E}$, alt. 780 m, 1 Aug 2009, C. Sato 3455 (MAK).
Based on the gross morphology, we initially assigned this unrecorded Sparganium species to S. japonicum. Upon closer examination, however, it was clear that the obovoid fruits of unrecorded species did not match S. japonicum (fusiform) (Cook and Nicholls, 1987). The narrower leaves and smaller size of the species is unique among other Korean Sparganium species, except $S$. hyperboreum. Thus we named $S$. subglobosum as Ka-neun-heuk-sam-reung (가는흑삼릉), although Chinese vernacular name is 狭叶黑三棱, also meaning narrow leaved Sparganium, to avoid confusion with the Korean name of $S$. hyperboreum, Jop-eun-ip-heuk-samreung (좁은잎흑삼릉).

Sparganium subglobosum was first described from the collections made by the U.S. Exploring Expedition to Bay of Islands, New Zealand (Morong, 1888). This species is one of only two Sparganium species appears in Southern Hemisphere in Australia and New Zealand, showing disjunct distribution 
A

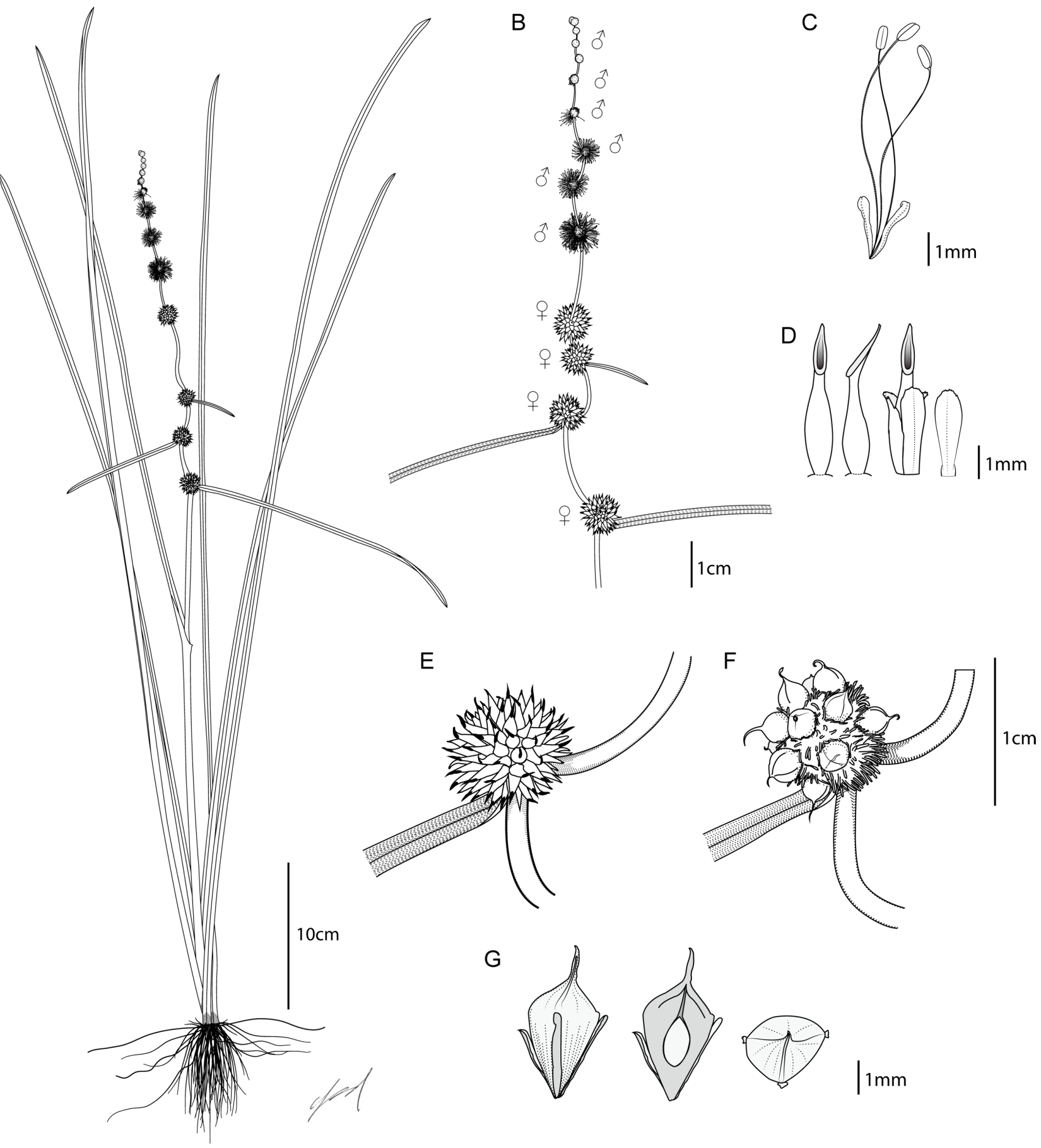

Fig. 2. Sparganium subglobosum Morong (Typhaceae). A. Habit. B. Detailed part of inflorescence. C. Male flower. D. Female flowers. E, F. Female heads. E. Female head at anthesis. F. Female head at fruiting. G. Nutlike fruit.

from Eastern Asia (Far Eastern Russia, northern China, Korea, Japan) to New Zealand, discontinously occurring in Yunnan, Vietnam, and New Guinea (Cook and Nicholls, 1987). The other species appearing in Southern Hemisphere is S. erectum, but probably introduced recently (Cook and Nicholls, 1987).
We have collected S. subglobosum from inlet of Lake Cheonjin, Goseong-gun, Gangwon Prov., where other endangered flowering plants, such as Nymphaea pygmaea var. minima and Brasenia schreberi, are also distributed. The other collection is made from wetland of Buk River (Bukcheon) near 
Bukcheon Bridge in Ganseong-eup, Ganseong-gun, Gangwondo, where $S$. erectum and S. japonicum is also collected. The two collection sites strongly suggest that $S$. subglobosum may distributed in wetlands along the eastern coast of Korea. Unfortunately, collection of S. subglobosum was only made from Lake Cheonjin during the 2010-2014 floristic survey project on the lagoon areas on the eastern coast of Korean Peninsula by National Institute of Biological Resources (NIBR), whose results presented in Kim et al. (2017) (also see Specimen examined). The inlet of Lake Cheonjin has recently been reclaimed by landowner and most of the habitat has been disappeared. Dr. Jin-Seok Kim at NIBR (pers. comm.) was able to find only a few individuals of $S$. subglobosum surviving this year. Although the Lake Cheonjin is very important and only habitat for several endangered plant species of Korea and the threat of disturbance has been expected, no serious measures and conservation action has been taken so far. Thus, conservation plans need to be prepared and enacted immediately, to protect the endangered species. Also, further survey of the coastal wetlands need to be done, to identify new distribution sites of $S$. subglobosum.

\section{Key to the Sparganium species of Korea}

1. Inflorescence paniculate. Female heads born on axillary branches with distinct axillary peduncle. Style mostly bifid. S. erectum 흑삼릉

1. Inflorescence branching one or two times only. Female heads mostly born on sessile on main axis. Style not branching.

2. Plants robust, $1-2 \mathrm{~m}$ high. Leaves wider than $5 \mathrm{~mm}$.

3. Proximal part of leaves triangular-flat in cross section, distal part flat. Inflorescence bracts spreading or ascending-spreading. Female heads usually axillary, long-pedunculate and upper ones approximate. Anthers $0.7-1 \mathrm{~mm}$ long.

S. japonicum 긴흑삼릉

3. Proximal part of leaves keeled, distal part keeledtriangular. Inflorescence bracts erect. Female heads usually supra-axillary and widely spaced. Anthers 1-2 mm long. S. fallax 남흑삼릉

2. Plants slender, shorter than $1 \mathrm{~m}$. Leaves narrower than $4 \mathrm{~mm}$.

4. Plant with mostly erect and emergent or rarely floating leaves. Leaves ususally longer than inflorescence, with distinct midrib and a keel abaxially. Stigmas 0.6-1 mm long. Beak 1-2 mm long.
4. Plants submerged or floating. Leaves flat, without distinct midrib and without a keel. Inflorescence simple, $2.5-4.5 \mathrm{~cm}$ long. Stigmas $0.3-0.5 \mathrm{~mm}$ long. Beak absent or nipple-like.

S. hyperboreum 좁은잎흑삼릉

\section{Acknowledgments}

Authors thank anonymous reviewers for their helpful comments on this manuscript. We also thank Drs. Goro Kokubugata and Tanaka Nobuyuki at National Museum of Nature and Science herbarium (TNS), Prof. Noriaki Murakami and Dr. Yukira Mochida at Makino Herbarium of Tokyo Metropolitan University (MAK), and Prof. Hidetoshi Nagamasu at Kyoto University Museum (KYO) for their help with herbarium work. Mr. Wunggi Lee at Daegu University made the drawing of S. subglobosum. This work was a product of the "DNA Barcode System for Korean Indigenous Plant Species (I)" project (NIBR201513201) of the National Institute of Biological Resources (NIBR), Ministry of Environment (MoE), Republic of Korea.

\section{Literature Cited}

Barrett, S. C. H., C. G. Eckert and B. C. Husband. 1993. Evolutionary processes in aquatic plant populations. Aquatic Botany $44: 105-145$.

Cook, C. D. K. 1988. Wind pollination in aquatic angiosperms. Annals of the Missouri Botanical Garden 75: 768-777.

Cook, C. D. K. and M. S. Nicholls. 1986. A monographic study of the genus Sparganium (Sparganiaceae). Part 1. Subgenus Xanthosparganium Holmberg. Botanica Helvetica 96: 213-267.

Cook, C. D. K. and M. S. Nicholls. 1987. A monographic study of the genus Sparganium (Sparganiaceae). Part 2. Subgenus Sparganium. Botanica Helvetica 97: 1-44.

Im, R. J. 2000. Flora Coreana, Vol. 8. The Science and Technology Publishing House, Pyongyang. Pp. 115-118.

Kim. C. and H.-K. Choi. 2007. Sparganiaceae. In The Genera of Vascular Plants of Korea. Park, C.-W. (eds.), Academy Publishing Co., Seoul. Pp. 1265-1267.

Kim, C.-S., S.-Y. Kim and M.-O. Moon. 2010. A new record for the Korean flora: Sparganium fallax Graebn. (Sparganiaceae). Korean Journal of Plant Taxonomy 40: 169-173.

Kim, J.-H., S.-Y. Kim, J.-K. Hong, G.-H. Nam, J.-H. An, B. Y. Lee and J.-S. Kim. 2017. Floristic study of lagoon areas on the eastern coast in Korean peninsula. Korean Journal of Plant Taxonomy 47: 51-93.

Kubitzki, K. 1998. Typhaceae. In Flowering Plants, Monocotyle- 
dons: Alismatanae and Commelinanae (except Gramineae). Kubitzki, K. (ed.), Springer Verlag, Berlin. Pp. 457-460.

Lee, T. B. 1980. Illustrated Flora of Korea. Hyangmunsa, Seoul. Pp. 296-297.

Lee, W. T. 1996. Linneamenta Florae Koreae. Academy Publishing Co., Seoul. Pp. 1438-1441.

Lee, Y. N. 2006. New Flora of Korea II. Gyohaksa, Seoul. Pp. $604-$.

Morong, T. 1888. Studies in the Typhaceae. II. Sparganium. Bulletin of the Torrey Botanical Club 15: 73-81.

Santamaría, L. 2002. Why are most aquatic plants widely distrib- uted? Dispersal, clonal growth and small-scale heterogeneity in a stressful environment. Acta Oecologica 23: 137-154.

Sun, K. and D. A. Simpson. 2010. Typhaceae. In Flora of China. Vol. 23. Acoraceae through Cyperaceae. Wu, Z. Y., P. H. Raven \& D. Y. Hong (eds.), Science Press, Beijing and Missouri Botanical Garden Press, St. Louis, MO. Pp. 158-163.

The Angiosperm Phylogeny Group. 2016. An update of the Angiosperm Phylogeny Group classification for the orders and families of flowering plants: APG III. Botanical Journal of Linnean Society 161: 105-121. 